Chapman University

Chapman University Digital Commons

Film Studies (MA) Theses

Dissertations and Theses

Spring 5-19-2019

\title{
Inflicted Viewing: Examining Moral Masochism, Empathy, and the Frustration of Trauma Cinema
}

\author{
Kira Smith \\ Chapman University, kirsmith@chapman.edu
}

Follow this and additional works at: https://digitalcommons.chapman.edu/film_studies_theses

Part of the Film and Media Studies Commons

\section{Recommended Citation}

Smith, Kira. "Inflicted Viewing: Examining Moral Masochism, Empathy, and the Frustration of Trauma Cinema." Master's thesis, Chapman University, 2019. https://doi.org/10.36837/chapman.000074

This Thesis is brought to you for free and open access by the Dissertations and Theses at Chapman University Digital Commons. It has been accepted for inclusion in Film Studies (MA) Theses by an authorized administrator of Chapman University Digital Commons. For more information, please contact laughtin@chapman.edu. 


\section{Inflicted Viewing: Examining Moral Masochism, Empathy, and the Frustration of Trauma Cinema}

A Thesis by

Kira Smith

Chapman University

Orange, California

Dodge College of Film and Media Arts

Submitted in partial fulfillment of the requirements for the degree of

Masters of Film Studies

May 2019

Committee in charge:

Kelli Fuery, Ph.D., Chair

Patrick Fuery, Ph.D.

Ian Barnard, Ph.D. 
The thesis of Kira Smith is approved.
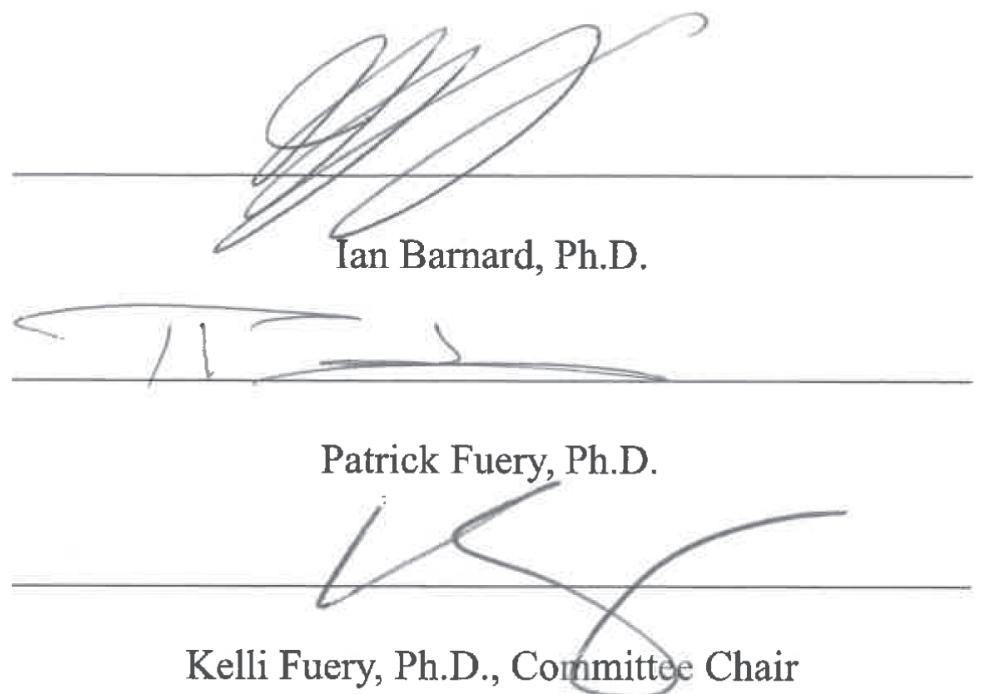

April 2019 
Inflicted Viewing: Examining Moral Masochism, Empathy, and the Frustration of Trauma Cinema

Copyright C 2019

by Kira Smith 


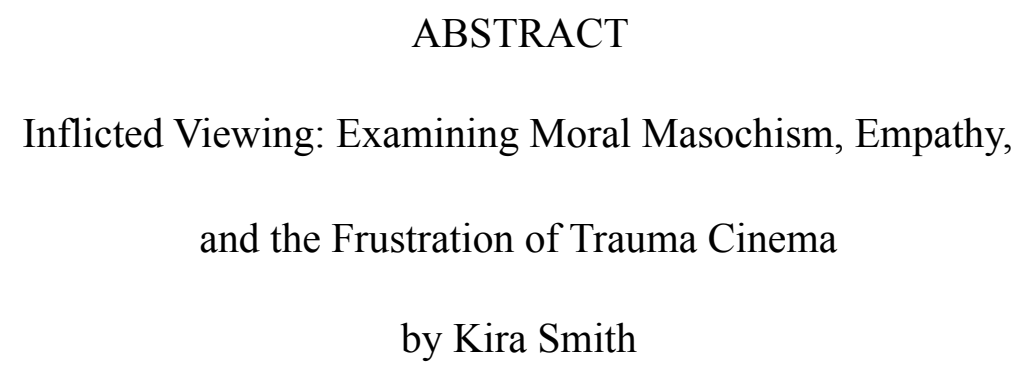

The contemporary turn of psychoanalytic film analysis has opened a new mode of understanding cinematic language. However, rejecting classical psychoanalysis would be premature. This thesis will place the two in conjunction, specifically through Sigmund Freud's conceptualization of moral masochism and Wilfred Bion's theory of thinking. Through four films: Una, The Tale, The Tribe, and Son of Saul I explore the affective nature of films that depict trauma and why one would gravitate towards such upsetting material. The spectator who seeks to be frustrated is not looking to harm oneself but to process this frustration in order to expand their emotional experience. 


\section{TABLE OF CONTENTS}

I. Introduction 1

II. Methodology 6

III. Literature Review 9

IV. Analysis 24

V. Una 25

VI. The Tale 28

VII. The Tribe 31

VIII. Son of Saul 33

IX. Conclusion 35

X. Bibliography 36

XI. Filmography $\quad 40$ 
I like to make people a little uncomfortable. It encourages them to examine who they are and why they think the way they do. - Sally Mann

Art has an inexplicable way of making us learn and change by disrupting something in our souls. American photographer Sally Mann has summarized this phenomenon beautifully by the way she hopes her art effects the onlookers, with slight discomfort. Stagnation and complacency seldom illicit change. There is a need for frustration in our lives to better understand how we deal with adversity and how we interact with the world. Many situations that cause us to grow and learn through discomfort are unintentional, a part of life. However, some shifts like ingesting art or films charged with less palatable content is self inflicted. Gravitating towards challenging art in this lens is a way to exert emotional pain onto yourself to build and grow stronger. In this sense being thrust into a filmic world, overflowing with emotionally traumatic events, allows for a self-reflective examining of your own capacity for unease.

Susan Sontag ruminates on the concept of experiencing traumatic imagery in Regarding the Pain of Others. In reference to George Bataille's obsession with a photograph of the execution of a Chinese prisoner in 1910, he elaborated on how it both excited and troubled him. Sontag clarified "Bataille is not saying that he takes pleasure at the site of the excruciation. But he is saying that he can imagine extreme suffering as something more than just suffering, as a kind of transfiguration."1 Frustration or 'suffering' is a catalyst to a wider range of emotional experience, there is a satisfaction in the ability to cope and endure where you can learn about yourself. Traumatic imagery 
like Bataille's photograph is inherently frustrating as trauma is so difficult to contest with. Trauma is a scar that will fade but never leave the skin, dealing or seeing with an irreconcilable event, ranging from the brutality of sexual assault to the mass genocide of war. There are many adages to expand on this phenomenon 'pressure creates diamonds' or 'a broken bone heals back stronger' creating an almost hostile example of how many things are bettered through destruction and rebuilding. Classic and contemporary psychoanalytic thinkers such as Sigmund Freud and Wilfred Bion, respectively, work through this quality of human experience from opposing schools of thought. Freud's pleasure-principle is in direct opposition to frustration, "we believe that any given process originates in an unpleasant state of tension and thereupon determines for itself such a path that its ultimate issue coincides with a relaxation of this tension, i.e. with avoidance of 'pain' or with production of pleasure."2 In Freud's theory, purposefully seeking displeasure is going against our nature, or there must be some kind of deviant pleasure derived from the situation. Starkly contrasting that point "Ferro and Foresti refer to Bion's theory of thinking as "The successful outcome of two mental processes: the formation of thoughts and the evolution of the apparatus required to cope with them" (Italics original, 2013: 365)"3 The ability 'to cope' is essential to Bionian psychoanalysis in order to evolve. Despite their individual approaches to psychoanalysis seeming to be in complete contradiction, aspects of their work can build on each other to

2. Sigmund Freud. 1924. "The Economic Problem of Masochism.” Essential Papers on Masochism. Edited by Margaret Ann Fitzpatrick Hanly. Essential Papers in Psychoanalysis. New York, NY: New York University Press. 1995.

3. Kelli Fuery. 2018. Wilfred Bion, Thinking, and Emotional Experience with Moving Images: Being Imbedded. Abingdon, Oxon; New York, NY : Routledge. pp. 3 
grow the understanding of this choice of self inflicted frustration. Re-contextualizing Freud's concept of moral masochism through Bion's theory of thinking and exploration of frustration, halts the deviant nature of masochism. This gives space to the unconscious urge to seek an understanding of the self through challenging viewing practices.

Classical psychoanalysis has been ingrained in film and media studies reaching back to Laura Mulvey's seminal article Visual Pleasures and Narrative Cinema (1973). With this bond between film theory and classical psychoanalysis there is a need to create space for contemporary, object-relations psychoanalysis, as well as a conversation between classical and contemporary. Many of the leaders of the movement toward contemporary have written to the lack of diversity in the schools of thought within conversations on film. Kelli Fuery in Wilfred Bion, Thinking, and Emotional Experience with Moving Images: Being Embedded elaborated that "a challenge to the traditional, classical models of psychoanalysis to examine emotional experience within moving image culture is not simply emerging but burgeoning." 4 It is my intention to add to this 'burgeoning' conversation by juxtaposing classic and contemporary psychoanalytic frames to examine the spectators emotional experience through modern melodramatic trauma cinema.

Janet Walker's 'trauma cinema,' is used as an umbrella term for films that depict the traumatic events of incest and the holocaust, in her book Trauma Cinema: Documenting Incest and the Holocaust. However, the term is not exclusive to those two traumatizing states, it can be widened to any film that centers around traumatic content,

4. Fuery. Wilfred Bion. pp 12. 
Walker even states "What I wish to explore, therefore, is the ability of certain films... to externalize, publicize, and historicize traumatic material that would otherwise remain at the level of internal, individual psychology." ${ }^{5}$ Trauma is an extremely difficult concept to understand, which will be elaborated on in more detail later in this paragraph, but because of this conceptual road block when it is depicted on film it lends itself to a melodramatic text. Even still, melodrama is a contentious term in and of itself, thought of as a film genre of stilted emotion and relegated to the outdated concept of the 'women's film.' On the contrary melodrama is not a genre, it is a mode of emotional excess. Christine Gledhill in The Melodramatic Field: An Investigation states that "the syphoning of unrepresentable material into the excessive mise en scène makes a work melodramatic."6 This term of the 'unrepresentable' is extremely important and creates an explicit link to melodrama and trauma. The inability to easily access trauma, whether the spectator has experienced it or not, makes watching a film that depicts or stylistically tries to represent trauma inherently frustrating and difficult to emotionally contend with internally. Walker elaborates on the 'unrepresentable' and 'unfathomable' aspects of trauma and the psychological damage that it causes to the victims memory of an event. ${ }^{7}$ Thus trauma's depiction through film is also inherently melodramatic. She defines trauma cinema as "films and videos that adopt catastrophe as their subject and formations of trauma as their

5. Janet Walker. 2005. Trauma Cinema: Documenting Incest and the Holocaust. Berkeley: University of California Press. pp XIX.

6. Christine Gledhill. 1988. "The Melodramatic Field: An Investigation. (Undetermined)." Home Is Where the Heart Is, January, 5-39. pp 9.

7. Walker. Trauma Cinema. pp XXI. 
aesthetic." ${ }^{8}$ However, Nikolaj Lübecker explores similar content in his book The FeelBad Film underlining that these films of unease or containing traumatic content do not fall into the framing of the body genres. His argument is centered on a catharsis or thrill from horror, porn, and melodrama that 'feel-bad' films do not meet. ${ }^{9}$ This carries on the misconception that melodrama falls into the same generic outlines as porn or horror.

Linda Williams in her article, which breaks down the body genres, even states that melodrama is not relegated into the same categorical framework as horror and porn, but was being used as such as a means to give it space in her argument. ${ }^{10} \mathrm{I}$ argue that the films I am analyzing hold true to the construct of melodrama, not outside of it in an ambiguous amputation of the body genres but squarely within them. Melodrama does not hinge on a cathartic end, it hinges on the emotionally charged content. Trauma is a uniquely emotionally charged subject, one that is not the coping of a moment but a scar embedded from the past. The concept of catharsis goes against the impetus of the emotional excess within melodrama. Stephen Prince examines catharsis through Aristotle, where the term finds its roots, as a way of purging feelings through language and acting. ${ }^{11}$ One does not experience this cathartic purge because of the inaccessibility of trauma, as Williams puts it, "in these fantasies the quest for connection is always tinged with the melancholy of loss. Origins are already lost, the encounters always take

8. Ibid., pp XIX.

9. Nikolaj d'Origny Lübecker. 2015. The Feel-Bad Film. Edinburgh Studies in Film and Intermediality. Edinburgh: Edinburgh University Press. pp 3.

10. Linda Williams. 1991. "Film Bodies: Gender, Genre, and Excess." Film Quarterly 44: 2-13. pp 11. Stephen Prince. 2000. Screening Violence. Rutgers Depth of Field Series. New Brunswick, N.J. : Rutgers University Press, c2000. pp 19. 
place too late, on death beds or over coffins." 12 Both trauma and melodrama are built on a disconnect from the past and the irreconcilability of pain, loss, and betrayal, the shrapnel of the unfathomable.

\section{METHODOLOGY}

To begin, this thesis will elaborate on previous theory to explore how trauma cinema can be a catalyst for change in the spectator. Rather than exploring spectatorship as a homogenous group of emotional experience I will focus on Tarja Laine's concept that there are "strategic and operational processes within the film, which can inform us about the 'salient techniques'... that evoke bodily affectivity and give semantic meaning to the cinematic experience."13 (Italics original) This allows for the reading of film to focus on intentionality, instead of broadly assuming individual responses of film goers. Briefly explored above, I will utilize contemporary and classical psychoanalytic theory as well as melodrama as a mode for the depiction of trauma cinema. Along with teasing out those concepts more, I intend to weave together concepts of spectatorship, like parallelism, contagion, and collective compassion, in order to explain the ability to empathize with and work through personal frustration using a media object such as film. In order to ground this text I will be following the hermeneutic methodology used also by Laine in Feeling Cinema: Emotional Dynamics in Film Studies, positioning myself "as a critical and attentive participant within the cinematic event"14 (Italics original).

12. Williams. "Film Bodies." pp 11.

13. Tarja Laine. 2011. Feeling Cinema: Emotional Dynamics in Film Studies. New York: Continuum. pp 4.

14. Tarja Laine. Feeling Cinema. pp 3. 
Objectively reading a text without acknowledgment of participation is a cold and distant way to interpret film. Writing about emotional response should have active and 'attentive' participation to experience what you are trying to prove.

This framework will be applied to interpret the emotional relationship between the four films I have chosen, that encapsulate trauma cinema while uniquely implementing formal and technical techniques, and the spectator. As trauma and melodrama work in concert, each film is contemporary which aligns with the concept that "melodrama [is] neither a historically stable genre nor one that remains fixed in its definition." ${ }^{15}$ Each film uses different formal techniques to cause frustration. These films demand attention and emotional investment through their artistic rendering and expand on the notion of the 'unrepresentable' using unique formal modes to illicit the spectators negative affect. Using different formal techniques they stand out from the traditional Hollywood structure. They also illustrate the universality of trauma, as each film is a product of a different county: Una was filmed in the UK ${ }^{16}$, The Tale in the USA ${ }^{17}$, The Tribe in Ukraine ${ }^{18}$, and Son of Saul in Hungary. ${ }^{19}$

Two of these films, Una (Andrews 2016) and The Tale (Fox 2018), explore the fallibility of memory as women come face to face with their experiences of being sexually assaulted and manipulated as children. Una examines the subjectivity of 15. Carla Marcantonio. 2015. Global Melodrama: Nation, Body, and History in Contemporary film. Palgrave Macmillan. pp 5.

16. Andrews, Benedict, et al. Una. Film4 Productions, 2016.

17. Fox, Jennifer, et al. The Tale. HBO Films, 2018.

18. Slaboshpytskiy, Myroslav, et al. The Tribe. Harmata Film Production, 2014.

19. Nemes, László, et al. Son of Saul. Sony Pictures Classics, 2015. 
memory and romanticization of trauma, while The Tale presents the breakdown of repression and pseudo memory which will be explored further later in this thesis. Una and The Tale being so similar in content allows for contrasted readings of their unsettling depictions of abuse. Both of these films use time and memory as narrative tools, shifting between the present, as these women deal with their trauma, and the past, when the traumatic events occurred. However, they differentiate stylistically showing the range of filmic transmission of frustration.

The Tribe (Slaboshpytskyi 2014) and Son of Saul (Nemes 2015) illuminate group trauma through gang violence and the Holocaust, respectively. These two films were chosen based on their distinctive experimentation with formal aesthetics, using the senses such as sight and sound to destabilize the viewer. Sound and perspective are borderline invisible pieces of film unless the traditional formula is shifted. The crucial piece of The Tribe's inclusion is its breakdown of communication. Throughout the entire film the characters communicate with each other through untranslated Ukrainian sign language, alienating the spectator. The film plays out in only ambient sound. Son of Saul on the other hand, focuses all of the attention on one man, there is a choreography to the actor and the camera where he never leaves the frame. We watch his experience of the holocaust with only seeing hints of it in the periphery. The carnage is just out of focus.

Relying heavily on the melding of many different aspects of psychoanalysis, spectatorship, and genre theory as well as an exploration on trauma and filmic representations of trauma. These concepts will be building toward the goal of arguing that choosing to watch, or rather gravitating towards, trauma cinema is a way to self 
inflict emotional frustration. Allowing film to cause oneself emotional frustration is a redefinition of moral masochism, as Freud sees masochism as a regression. 20

Contrarily, moral masochism can be an unconscious urge to progress by building, "a capacity for tolerating frustration thus [enabling] the psyche to develop thought as a means by which the frustration that is tolerated is itself made more tolerable." ${ }^{21}$ With this shift, there no longer needs to be an emphasis on an "erotic component"22 of libidinal gratification rather the focus on, "instincts of self-preservation," 23 within the libido theory. As this can be a way to elaborate on self-understanding by testing the limits of one's own tolerance for frustration, thus improving emotional experience not satisfying an erotic perversion of masochism.

\section{LITERATURE REVIEW}

Sigmund Freud's papers "Beyond the Pleasure Principle" and "The Economic Problem of Masochism" (1922: 1924) lay out simple explanations of Freud's core concepts such as, 'the pleasure-principle,' 'the reality-principle,' and 'moral masochism.' The core concepts listed here give an entry point to his work without being overtly caught up in the libidinal aspects of drive-gratification. The pleasure-principle as elaborated on above, is humans natural state of pain avoidance but, the reality-principle is needed

20. Sigmund Freud. 2015. "Beyond the Pleasure Principle." Psychoanalysis and History, Sigmund Freud, Beyond the pleasure principle: New critical edition by Ulrike May and Michael Schröter, with commentary, 17 (2). pp 70.

21. Wilfred Bion. 2013. “The Psycho-Analytic Study of Thinking.” Psychoanalytic Quarterly. http://icpla.edu/wp-content/uploads/2014/09/Bion-W.-A-theory-of-thinking-The-PsychoAnalyticStudy-of-Thinking.pdf. pp 3.

22. Freud. "The Economic Problem" pp 283.

23. Sigmund Freud. "Beyond the Pleasure Principle." pp 70. 
because the world sometimes makes it impossible to avoid pain and explains humans choice to prolong discomfort for future satisfaction. ${ }^{24}$ The explanation for moral masochism starts in expressions of self-punishment and a conscious feeling of guilt in Freud's patients. However, Freud complicates this conscious sense of guilt and personal choices to be involved in frustrating situations to be linked to an unconscious internal battle between the 'ego' and 'super ego' or the want for external parental punishment. 25 This line of thought, and need to bring a conscious and understood concept and reverse engineer an unconscious sexual drive is where Freudian analysis, in my reading, becomes convoluted. Rather than interpreting this urge for frustration as an unconscious oedipal urge 26 or a paradoxical "fusion of instinct" where,

Its danger lies in the fact that it originates from the death instinct and corresponds to the part of that instinct which has escaped being turned outwards as an instinct of destruction. But since, on the other hand, it has the significance of an erotic component, even the subject's destruction of himself cannot take place without libidinal satisfaction. ${ }^{27}$

As the death instinct in masochism is being turned at once against the self ${ }^{28}$ yet also escaping outwards 'as an instinct of destruction,' how then is there still a sexual and self preserving satisfaction within moral masochism? In order to make this a tangible less cyclical idea it could be seen as an unconscious want for self examination and growth.

24. Sigmund Freud. "Beyond the Pleasure Principle." pp 20.

25. Freud. "The Economic Problem.” pp 282.

26. Ibid., pp 271.

27. Ibid., pp 283.

28. Ibid., pp 279. 
With the turn of destruction kept internal, one can use media objects to create the destructive turmoil, which is then needed to be processed in order to rebuild a stronger base of emotional experience. This concept creates an entry point for contemporary and classical psychoanalytic frames to work in tandem.

Wilfred Bion and D.W. Winnicott were the forefathers of object-relations psychoanalysis, they opened up a school of thought that can allow for a more nuanced reading of moral masochism. Two books have been pivotal in my research on Bion's psychoanalytic theory and how it can be related to film; Wilfred Bion, Thinking, and Emotional Experience with Moving Images: Being Embedded (Fuery 2018) and Bion in Film Theory and Analysis: The Retreat in Film (Ambrósio Garcia 2016). Fuery's Being Embedded interprets Bion's theories clearly in relation to the study of motion picture. Within Bionian psychoanalysis it is emphasized that the ability to interpret frustrating emotional states, it requires an 'other mind' to work through it with you, rather than in isolation. Fuery argues that this 'other mind' which we use to think through can be a film. ${ }^{29}$ This leads into D.W Winnicott's Playing and Reality (Originally published in 1971), a primary text in object-relations psychoanalytic theory, which provides a framework for how we can use film as an object where inner thoughts and external experience coincide separately but also work together. ${ }^{30}$ Having the ability to understand yourself more through these bouts of frustration also can be understood through Jens Zimmermann's Hermeneutic: A Very Short Introduction (2015), where the ability to

29. Fuery. Wilfred Bion. pp 44.

30. Donald W Winnicott. 2008. Playing and Reality. Routledge Classics. Routledge. pp 3. 
learn becomes internalized and can be expressed in new ways. ${ }^{31}$ This is a simple concept of knowledge but with learning our boundaries and pushing past them this ability to tolerate is inwardly engrained. One can work through film as a way to create and think through discomfort. The ability to deal with frustration allows for the development of coping mechanisms for future frustration..$^{32}$ Garcia explicitly states "Bion is concerned with the capacity to suffer because he recognizes the connection that exists between pain and growth" 33 To reiterate the connection between this 'capacity to suffer,' as a way to grow points to the reasoning why one would self inflict frustration through moral masochism. This interplay of emotional experience and state change is a stepping stone to acceptance of 'the truth. ' ${ }^{34}$ In order to understand these emotional experiences, there needs to be an object to work through them, Bion himself wrote of the importance of communication to give internal, and individual thoughts truth..$^{35}$ In his writings it was a conversation between two people, or analyst and analysand, however, film can also be an object that is thought through as a way to communicate and relate without an explicit verbalization of thoughts. ${ }^{36}$

31. Jens Zimmermann. 2015. Hermeneutics: A Very Short Introduction. Very Short Introductions. Oxford: Oxford Univ Press. pp 7.

32. Fuery. Wilfred Bion. pp 41.

33. Garcia, Carla Ambrósio. 2017. Bion in Film Theory and Analysis: The Retreat in Film. New York, NY: Routledge/Taylor \& Francis Group. pp 46.

34. Fuery. Wilfred Bion. pp 31.

35. Wilfred R Bion, 1984. Second Thoughts: Selected Papers on Psychoanalysis. London: Routledge. pp 119.

36. This is similar to writings of Dr. Fuery and Ambrósio Garcia (film as object or relational tool) 
Film as the object of frustration, requires frustrating and emotionally charged content to be able to work through and with. As a filmic mode melodrama and as content trauma create a perfect storm of incredibly difficult viscerally uncomfortable experiences for the viewer. As explored above melodrama is a mode of emotional excess, where trauma finds an experiential footing that mirrors the real life complexity of emotionally dealing with trauma but at a moderately safe distance. Walker in Trauma Cinema: Documenting Incest and the Holocaust (2005) explores films and videos dealing with the trauma of incest and the holocaust and explores the dissonance of event and memory of the event. Representations of trauma on film, even by those who experienced them, are 'disremembered' from the actual events that occurred. 37 There is a disconnect because trauma is an 'unfathomable' 38 occurrence that is nearly impossible to mentally quantify, creating a dissonance between reality and memory. There is again a connection between Walker and Christine Gledhill's The Melodramatic Field: An Investigation, where melodramatic films must find avenues to represent the 'unrepresentable,' whether that includes Sirkian subtext or manipulations of formal aesthetics. ${ }^{39}$ Gledhill's work is not in direct reference to the unfathomability of trauma, however the parallels between the blockage of expression of taboo subjects ${ }^{40}$ and the inability to fully express trauma are exceedingly copasetic. Melodrama also works well as the case study for this object-relating moral masochism because of its ambiguity. In

37. Walker. Trauma Cinema. pp XXII.

38. Ibid., XII.

39. Gledhill. "The Melodramatic Field." pp 30.

40. Ibid. 
Gledhill's book she quotes Peter Brook's The Melodramatic Imagination (1976), illustrating the lack in 'moral outcome' to melodrama giving the films a layer of open interpretation. ${ }^{41}$ Anecdotally, Paul Thomas pulled a moment from an interview of Rainer Werner Fassbinder, a melodramatic director, stating "Hope...does not exist in my films. It can only be born in the head of the audience." ${ }^{42}$ Harkening to a concept examined by Lübecker where there is cathartic dead-lock due to, confrontation between Brechtian aesthetic and the surrealist invitation to immersion whereby these two aesthetics arrest each other: on the one hand, we are not given the distance that Brecht recommends; on the other, we are deprived of the cathartic release that Artaud and Bataille aim for. ${ }^{43}$

However, finding catharsis within the film itself is not necessary, this dead-lock allows for the film to sit with the spectators longer, where the frustration of non-catharsis becomes the hope or further understanding in the head of the spectators after the credits have rolled. Not having this cathartic release easily accessible within the traumatic film text arouses a collaboration between the concepts depicted and the spectator, Abraham Geil argues this point in The Spectator without Qualities, where he explores the ideas of philosopher Jacques Rancière. "This is a spectator who does not simply judge or take pleasure and pain in a work of art but is 'summoned into the reinvention of the work' and, as Rancière puts it, 'comes to collaborate in the work as he looks at it' (Rancière 2011d:

41. Ibid., pp 33.

42. Paul Thomas. 1976. "Fassbinder: The Poetry of the Inarticulate." Film Quarterly 30 (2). pp 6. 43. Lübecker. The Feel-Bad Film. pp 27. 
297). ${ }^{44}$ The ability to tolerate 'open endings,' where there is no cathartic or satisfactory end creates a gap where the spectator must cope with and understand what this open interpretation means to them and how it made them emotionally react and why: selfreflection encourages self-awareness and internal change. 45

The ability to weave together a psychoanalytic framework to argue melodrama and trauma as valid and worthy case studies is only half of the work at hand. Spectatorship theory is where the ability for trauma cinema to viscerally effect and frustrate the viewer is considered. Two sources steadied my understanding, not only of the ability film has to move someone emotionally, but also the role trauma can have in the nature of the affective qualities that allow for emotional processing. Tarja Laine's Feeling Cinema: Emotional Dynamics in Film Studies (2011), is broken down into seven different emotional experiences and explores each through 'affective appraisal' and 'emotional evaluation,' she puts these two concepts together in her term 'cinematic emotion.'46 In her synthesis of trauma as an emotional experience she employs empathy as the connecting factor between the screen and the spectator's cinematic emotion. The breakdown of empathy exhibited in Laine's chapter on trauma moves through multiple possibilities of relating to the characters or situation in the film. Quoting Hugo Münsterberg, "the feelings of the person in the [film] are transmitted into our own

44. Geil, Abraham. The Spectator without Qualities. 2013. Edinburgh University Press. https:// www.academia.edu/10353920/The_Spectator_without_Qualities. pp 65.

45. Fuery. Wilfred Bion. pp 31.

46. Laine. Feeling Cinema. pp 2. 
soul." 47 This idea of transmission gives empathy a contagion like quality where the emotions of others are contracted when paying attention to their situations. 48 Teresa Brennan details the difficulty of pinpointing contagion within affect and how emotions or feelings could be transmitted. Jumping between many theorists she discusses the importance of seeing and hearing the person who is affecting the other, though there are many who criticize the assertion of this idea, "but the emphasis is not really challenged."49 However, Laine specifically speaks to the empathetic reaction to melodrama through 'parallelism' where a second world is created by the viewer. "At the same time this parallelism allows a mode of affective participation in the cinematic event that imposes the effect of trauma upon the spectator through conditionality, or rather modality." 50 Within melodrama, and particularly within trauma cinema, the spectator might not have an experience anything like what they are seeing on screen though through parallelism this event can be imagined. This allows the spectator to 'genuinely think' and engage with the uncomfortable content which was explored earlier speaking on Bion's theory of thinking. Fuery, quoting one of Thomas Ogden's 'principals of mental functioning,' notes that it takes 'two minds to think one's disturbing thoughts." 51 Parallelism allows for two or more minds to work through a particular frustration through

47. Laine. Feeling Cinema. pp 46.

48. Ibid.

49. Teresa Brennan. 2004. The Transmission of Affect. Ithaca: Cornell University Press, 2004. pp 57. 50. Ibid., pp 47.

51. Fuery. Wilfred Bion. pp 33. 
the imagination of the content being projected. Film and parallelism helps in creating a conception of how to create self-awareness and find commonality with others. ${ }^{52}$

In a separate, though not mutually exclusive theory on empathy, Lisa Cartwright lays out in the conclusion of Moral Spectatorship: Technologies of Voice and Affect in Postwar Representations of the Child (2008), that empathy can be felt towards someone that could be 'their responsibility.' 53 This plays on the idea that as a collective society we care for and feel for each other as a group. ${ }^{54}$ Seeing someone we consider to be part of our group or someone we should socially watch out for, like children in pain or hurting, we feel compassion and empathize. Janet Stadler in Pulling Focus: Intersubjective Experience, Narrative Film, and Ethics, sees attending film as a way to escape personal troubles and be compassionate to the subjects within the film. "People go to the cinema specifically to see, hear, feel, respond, and attend to the film: spectators' priorities shift from personal concerns to a story concerning others." ${ }^{\prime 55}$ This paper argues that those who watch trauma cinema are not fully shifting away from the personal but uses the concern and frustration felt about the 'story containing others' as a medium for understanding the self. Shifting the concerns are more interrelated rather than separate as Stadler's quote seems to suggest, but illustrates a shift in using the filmic object. She continues to quote phenomenologist Harald Stadler who states that there is a relationship between the

52. Jane Stadler. 2008. Pulling Focus: Intersubjective Experience, Narrative Film, and Ethics. Continuum. pp 5.

53. Lisa Cartwright. 2008. Moral Spectatorship: Technologies of Voice and Affect in Postwar Representations of the Child. Durham : Duke University Press. pp 235.

54. Ibid., pp 236.

55. Stadler. Pulling Focus. pp 42. 
spectator and the film, as the spectator brings their own experience to reading of the film ${ }^{56}$. However, she does not engage directly with this idea of past experience having an effect on the relationship between the spectator and the film. Her breakdown of spectatorship is also limited to film as an "enjoyable activity" 57 where she specifically lists the outdated concepts of voyeurism, scopophilia, and the "gazing upon the celestial bodies of film stars" 58 as the primary pleasures of the cinematic experience. These concepts still have merit in the reading of film texts, but the overarching idea that film is only used as a pleasurable experience for spectators is reductive. The stars are no longer "just a screen image" to be marveled at "but a flesh and blood person." 59 Many scholars and I explore the spectrum of reactions and experiences tied to film. Cartwright also touches on the concept of contagion, like Laine, that feelings of an other can 'infect' a group dynamic even if that other is not a part of your immediate group. 60 Empathy does not require identification, nor does it require the spectator to have experienced what the character is going through. Anna Gibbs in her article Panic! Affect Contagion, Mimesis and Suggestion in the Social Field, elaborates on a slightly different experience of group contagion through 'imitation,' where we habitually sympathize and respond accordingly to what is 'suggested by other bodies. ${ }^{91}$ This concept can also be linked to the work

56. Stadler. Pulling Focus. pp 43.

57. Ibid., pp 42.

58. Ibid., pp 43.

59. Richard Dyer. 2004. Heavenly Bodies : Film Stars and Society. London ; New York : Routledge, 2004. pp 9.

60. Cartwright. Moral Spectatorship. pp 236.

61. Anna Gibbs. 2011. "Panic! Affect Contagion, Mimesis and Suggestion in the Social Field." Cultural Studies Review, Vol 14, Iss 2 (2011), no. 2. pp135. 
mentioned above by Brennan, where this suggestion could be interpreted through sight and sound, working between the film and the spectator or, if the film is being seen in a theatre setting, with those around experiencing the same film.

With these theories of spectatorship, collective compassion, contagion, collaboration, and parallelism spectators are immersed into the unknowable frustrating world of trauma cinema. Christopher Bollas speaks on the "highly encrypted moments" of the dream and the mental breakdown in Catch Them Before They Fall: The Psychoanalysis of Breakdown, "It is not a matter of intellection but of immersion in the material, in order that the mind can elaborate the encoded condensation through further unconscious work, laced with emotional experience and insights."62 This quote encompasses those two functions however, in psychoanalytic thinking the dream or 'waking dream thought' can be equated with the filmic world. This all encompassing world of trauma cinema is a catalyst for 'unconscious work' where the frustration, in this case of a mental breakdown, leads to breakthroughs in personal growth and understanding of oneself. The suffering from watching a traumatic film still carries weight of moral masochism because the suffering does not need to be pain from another person. "The suffering itself is what matters... It may even be caused by impersonal powers or by circumstances; the true masochist always turns his cheek whenever he has a chance of receiving a blow." ${ }^{63}$ Freud's overarching framework for masochism gives the ability for almost any object or other to be the impetus of

62. Christopher Bollas and Sacha Bollas. 2013. Catch Them Before They Fall: The Psychoanalysis of Breakdown. New York, NY: Routledge/Taylor \& Francis Group. pp 86.

63. Freud. "The Economic Problem.” pp 279. 
suffering, and the film object is uniquely situated to be used again and again, from rewatching films to picking up or going to see another traumatic film. Spectators who gravitate toward immersing themselves into traumatic and frustrating worlds are better able to tolerate and gain insight of themselves. "A capacity for tolerating frustration thus enables the psyche to develop thought as a means by which the frustration that is tolerated is itself made more tolerable." 64 The entire world, then, becomes more tolerable, and the spectator more in touch with their own emotional experience to collaborate with and work through trauma cinema.

\section{$\underline{\text { ON EMOTION }}$}

Without an understanding of 'emotion,' the hinge of emotional experience and frustration falls apart. Laine as mentioned above coined the term 'cinematic emotion' capture the concepts of 'affective appraisal' and 'emotional evaluations.' 65 This over arching term is exemplary in how affect and emotion work hand in hand. Affect is more ambiguous to describe as it is consciously unknowable, however emotion is the processing of that unknowable feeling. In more precise words Laine explains it as an emotional evaluation is the semantic account of the affective appraisal that can be narrated and remembered... Affective appraisal, such as the flash of anger or the sudden weigh of despair, strikes the body, immediately in and through the flesh. But emotional evaluation collects and gives meaning to the 'surplus' of affective appraisal by transforming it into a memory. 66

64. Bion. Second Thoughts. pp 112.

65. Laine. Feeling Cinema. pp 2.

66. Ibid., pp 2. 
The body feels and the mind tries to understand why through emotional processing. Lübecker, touches on affect without using that term. Instead he uses the term 'intensities' that try to cause a shift in the feeling of the spectator. ${ }^{67}$ Describing affect as an intensity can be found in the introduction to A Thousand Plateaus: Capitalism and Schizophrenia, "It is a personal intensity corresponding to the passage from one experiential state to another." 68 Unlike affect emotion has a word associated with it, happiness or sadness, possibly even a function such as tears. Eugenie Brinkema's The Forms of the Affects (2014), explores how tears are reactionary, tears are an emotional response to affect "in this case, tears come after." ${ }^{69}$ Emotion is the cognitive processing of affect, it is something that can only be understood through experience. The ability to tolerate frustration or unease allows space for understanding that emotion, and to echo back to Mann's quote, we can examine why we react the way that we do, thus increasing our emotion equity. This increase allows us to be open to new concepts, ${ }^{70}$ tolerate uncomfortable situations, ${ }^{71}$ and have an increased self-awareness. ${ }^{72}$ To relate this back to film's influence on our emotional growth Carl Plantinga states it quite succinctly:

67. Lübecker. The Feel-Bad Film. pp 2.

68. Brian Massumi. 2013. "Translator's Forward: Pleasures of philosophy," A Thousand Plateaus : Capitalism and Schizophrenia. Deleuze, Gilles. Bloomsbury Revelations Series. Bloomsbury. pp XVI.

69. Eugenie Brinkema. 2014. The Forms of the Affects. Durham, NC: Duke UP. pp 9.

70. Garcia. Bion in Film Theory. pp 48.

71. Ibid., pp 46.

72. Fuery. Wilfred Bion. pp 31. 
Films may generate the cognitive revaluation (revision or rethinking) of a prior emotional response. This sort of cognitive revaluation results from the evolving experience of the narrative... In other words, cognitive revaluation, when and if it occurs, may be a component of the emotional appeal of the narrative. ${ }^{73}$ His conceptualization of state change while watching film falls outside of the realm of psychoanalytic theory, as he argues more for an emphasis on cognitive psychology, it is still relevant to what this thesis is trying to synthesize. Understanding oneself and being able to cope with the emotions a film can create in the spectator is a reason why we want to watch film, even traumatic film.

As an additional ending point to the concepts of affect and emotion is this quote by Emma Wilson, in her writings on the holocaust documentary Night and Fog (1956) "Material remains: Night and Fog," she states,"Whether or not the images captured are authentic or staged, Resnais edits those images together in a bid to unsettle how and what we see, to make the visceral shudder of the indeterminacy of living and dead matter, a moment of unknowing and undoing the viewer..."74 (2005). Her description of unraveling the spectator through the formal and technical qualities of the film highlight how films affective quality is so difficult to pin down. 'unknowing' and 'undoing' give a sense of discomfort and unease but without fully being able to place it, except with this more vague ambiguous language. The quote itself is charged as well pulling me in as a reader to understand the way this film made Wilson feel. This kind of writing I hold as a source of inspiration for how to

73. Carl Plantinga. 2018. Screen Stories: Emotion and the Ethics of Engagement. New York: Oxford University Press. pp 47.

74. Emma Wilson. 2005. "Material Remains: Night and Fog.” October 112: 89. pp 120. 
explain and interpret a films affective and emotional quality. Wilson as well as Lübecker, Laine, and Vivian Sobchack also inspire the way I will be analyzing film texts. Laine's position of 'attentive participation' has been a commonality through these scholars' work, and by no means is that a comprehensive list of scholars who subscribe to this style of analysis but those whose text have been pivotal to my work.

As the subject matter explored below is incredibly sensitive, there will not be much discussion about the moral implications of showing traumatic events but the emotional experience. There is plenty of room to think through the technological innovation of face mapping, which I will be discussing in more detail below, and using it to portray illegal acts, specifically against children. However, for the context of this work it is too large of an area to cover in the following pages and deserves to be thought through and discussed in its own paper.

The ability to empathize with or through film creates an atmosphere in a theatre or behind the screen of a laptop that allows for a change in emotional state. Choosing to watch a film that is emotionally complex and unsettling putting you in a state of unease or frustration is in and of itself moral masochism. Allowing this frustration to persist while watching a film, tolerating it, not immediately changing the the channel or walking out of the theatre, expands your emotional intelligence. The internal struggle to try and understand your self or your capacity for discomfort cannot happen in a comfortable vacuum but can be challenged by a working through or working with media objects. These media objects can take many forms to create frustration, this thesis is not trying to argue that cringe 
comedy could not be an effective catalyst for frustration however, I make a case that melodramatic trauma cinema is highly affective and effective in creating frustrating emotional shifts within the viewer.

\section{$\underline{\text { ANALYSIS }}$}

To explore the concept that self inflicted viewing of trauma cinema is a part of moral masochisms function to cause frustration and create change within the spectator I will individually discuss scenes from the traumatic films listed previously and how they create an emotionally frustrating spectatorial relationship where personal change can be made. Utilizing seemingly opposing psychoanalytic theories to work in concert while illuminating the benefits of trauma films. According to Freud moral masochism causes and internalizes guilt for enjoying the negative or painful 75 , but if we can expose why there can be a positive outcome from moral masochism, there is no need to feel guilt for experiencing the negative, when there can be personal growth and understanding from discomfort. To highlight the positive growth and self awareness that can come from frustration, Bollas wrote this on a patient's experience of working through a mental breakdown, "Transforming the raw scars of the past into an emotionally coherent history was deeply relieving and integrating. Disparate parts of his personality came together, and a man whose self-understanding had been very limited suddenly found himself making sense." ${ }^{\prime 76}$ Not to conflate an individual psychoanalytic case to the spectrum of human experience, but to show the beneficial outcome of emotional frustrating and

75. Freud. "The Economic Problem.” pp 279.

76. Bollas. Catch Them Before. pp 99-100. 
difficult experiences that can cause positive growth and change. This case was through intense psychoanalysis of the patient however, on a micro level film allows for the spectator to collaborate with their own experiences and personal understanding to create their own 'coherent history', and build a self 'understanding.'

\section{$\underline{\text { UNA }}$}

Una flashes between scenes of tranquility and scenes of sensory overload, the loud music and flashing lights of a club cut to Una quietly sitting in her car. Throwing the audience to the edge of their seat within the first ten minutes. The film continues to destabilize the viewer by cutting between the past when when Una's neighbor started an inappropriate relationship with her, his trial for kidnap and rape, and the present, years after he was released from his prison sentence. The film juxtaposes a tender and beautiful rendering of the past, as Una (Rooney Mara) herself holds her memories in fondness and the gritty stark warehouse space where she confronts the man who assaulted her (Ben Mendelsohn). Una, who never repressed or forgot this relationship must come to terms with the gravity of something she saw as an innocent romance that scarred her life. Her past with him is painted in a soft, dreamlike quality, the room they shared together is light with curtains slowly flowing in the breeze. These establishing shots cut to a similarly calm frame of their hands in extreme close up, the disconnect of her small hands resting in his push away any semblance of ignorance of the traumas that we never see, the abuse that hides behind closed doors. There is a contrast between the idyllic and atmospheric handling of the shot and the perverse act being alluded to, this creates an example of what Geil explores with Rancière's term 'dissensus:' 
'a rupture in the relationship between sense and sense, between what is seen and what is felt. What comes to pass is a rupture in the specific configuration that allows us to stay in "our" assigned places in a given state of things' (2010: 143). That rupture severs the logic of cause and effect that would mark out a path from the viewing of a film to a given awareness about the world and from that awareness to political action. ${ }^{77}$

It can be argued that political action is not always stirred, but internal change can be made from the discomfort or' rupture' of homeostasis when confronted with such subject matter. This trauma impacting a little girl is no longer happening behind closed doors, watching this film forces us to come to terms with the reality of the world and 'engage in genuine thinking'78 This genuine thinking is using the film as the 'other mind' in "Ogden's second second principle of mental functioning in Bion's theory of thinking." We use the media object as a way to experience this disturbing thought, and work through the reaction to the subject matter. Giving a self-awareness to the personal conceptualization to a part of the world that you may never come into contact with.

In another particularly affecting scene Una's neighbor, Ray, is sat on an unassuming bench in a park as he watches young Una walk through the crisp grass. A moment that can be recognized from a typical Sunday afternoon at any park bringing up a collective memory of, seeing children play, going to the park with a young family member, a simple and identifiable scene from the innocent everyday life. Seeing this young girl walk through the park allows the spectator to "imagine themselves as part of a

77. Geil. The Spectator without Qualities. pp 55.

78. Fuery. Wilfred Bion. pp 33.

79. Ibid. 
'we' that shares the responsibility. This kind of empathy is at the core of sociality, and of shame." 80 Una is every child that has walked through a park, someone to be cared for and protected. She disappears from view, behind a shrub, and Ray walks to the same spot and disappears behind the leaves. Excruciatingly slowly the camera pushes into the peaceful rustle of the leaves until the screen is nothing but shades of green. Una's voice is at the edge of tears as she bitingly narrates and describes the molestation taking place only feet from the perspective of the camera, still ever so slightly moving closer to the bushes building sickening tension.

There pain in Una's voice is a mix between loss and hatred, like venom hitting our ears contrasted by the calming imagery, this turns the once serene park into a sinister place. We are primed to imagine the acts being perpetrated just beyond the screen. "For mature mental functioning to occur, a person (or group) must be able to hold multiple perspectives of reality in their psyche across time." $" 11$ The space of the long take is intended to facilitate these 'multiple perspectives' and fully realize what is happening, to not only see the greenery but imagine the act and understand the weight of the what is happening within the film world. Having that time creates 'parallelism' as per Laine, "At the same time this parallelism allows a mode of affective participation in the cinematic event that imposes the effect of trauma upon the spectator through conditionality, or rather modality." ${ }^{2}$ Not only are we given a space to imagine through oral description of what is taking place but the film giving the sense of sight a reprieve to imagine the scene 80. Cartwright. Moral Spectatorship. pp 236.

81. Fuery. Wilfred Bion. pp 32.

82. Laine. Feeling Cinema. pp 47. 
Una is describing. Long take functions as a way to have the mind wander, also known as reverie, as Fuery quotes Avner Bergstien "reverie makes it possible to listen to what happens in the gap [between two minds]." 83 Taking the film as the second mind, this break in visual stimulus creates the gap where we place the horror. Imagining something so unfathomably difficult, makes its existence known. Coping with this does not mean to say one can come to term with the sexual abuse of a child, but one can process the fear of it instead of acting on the visceral negative emotions that come with such material, but one can react with logic.

\section{THE TALE}

The Tale is unique in the line up of films I have chosen to analyze because it is based on the filmmaker, Jennifer Fox's, personal experience with recovered memories of her own sexual assault. Through flashback this film touches on a concept discussed by Walker “... traumatic events are remembered awkwardly_-"disremembered,” I will say — by the people who live through them or experience them vicariously and, crucially, by the films and videos that result." ${ }^{" 84}$ As the film opens we see images of a young girl at a horse riding camp as she narrates the memories of her beloved instructor, the memories are rosy and full of childish delight. They are narrated from journals that Jennifer (Laura Dern), the character, finds in her mom's home. The memories start to fracture the further she gets into the journals as the 'disremembered' events come back into focus. The image she hold of herself was mature for her age,

83. Fuery. Wilfred Bion. pp 50.

84. Walker. Trauma Cinema. pp XXII. 
almost finding a justification to the manipulation and "relationship" she would have with her riding instructor and the man who worked near by. However, a photo album reveals the fallibility of her own memory with an image of the young Jennifer (Isabelle Nélisse). The image of herself that she had been projecting onto the past was years older then her true age. This realization crashes down onto Jennifer's memory as a scene that had been played earlier in the film is repeated but, the the older actress is replaced with the younger, and we finally, truly, see a child.

Distinctly, The Tale bravely and controversially depicts sexual acts agains a child through the use of a body double for young Jeniffer. As the man manipulating or "priming" Jennifer finally has her comfortable enough to pursue sexual advances, the film explicitly breaks down any semblance of comfort for the spectator. Unlike Una, and many other films with similar subject matter, there is no avoidance of trauma. Young Jennifer is about to perform oral sex on the older man but the film does not cut away to a more suggestive framing. Jennifer Fox, the director, expressed the need to show the reality of what happened to her, "It needed my authority." 85 This choice breaks down the typical agreement between the spectator and the screen, not hiding the reality, because the reality is devastating without the formal traditions of alluding to this perversion. While both directions are valid, Münsterberg outlines the power of breaking formal tradition, "The value of these formal changes for the expression of the emotions may become remarkable. The characteristic features of many an attitude and feeling which cannot be

85. Phoebe Reilly. 2018. “Is ‘The Tale’ HBO's Most Controversial Movie Ever?” Rolling Stone. https://www.rollingstone.com/tv/tv-features/is-the-tale-hbos-most-controversial-movieever-630017/ 
expressed without words today will then be aroused in the mind of the spectator through the subtle art of the camera." 86 Münsterberg was writing at the beginnings of cinema, this work originally being published in 1916, hypothesizing how film would change as an art form. His ideas were incredibly ahead of their time, the 'subtlety of the camera' is intrinsic to filmmaking, and is highlighted in the nuance of melodrama. However, his ideation works in the reverse in this case. This sensitivity has become commonplace and art, in this case, has shifted to art that uses shock as the mode of arousing emotional shifts in the spectator. The shock of the act was not only a depiction os assult, but also an assault on the spectator "The semiotic richness of screen texts entails an embodied engagement and often elicits a visceral response that is linked to the appeal that the medium makes not only to the intellect, emotions, and imagination, but in the way it actively engages the physical senses." 87 When watching this scene I audibly protested, alone in my room, in complete awe and horror of what I was witnessing. Feeling almost like I was an unwilling accomplice to this illegal act. These realities are not at the forefront of everyday life, "the paradoxes that are repressed in everyday discourse, and to elicit perverse, disturbing and pleasurable experiences that enlarge our capacity to imagine the world and our relations anew (Bishop 284)"'"88 Seeing such a raw depiction of the sexual manipulation and assault of a child, gives a different light to the way one sees the world.

86. Hugo Münsterberg. 1970. The Film: A Psychological Study: the Silent Photoplay in 1916. Dover Books in Psychology. Dover. pp 56.

87. Stadler. Pulling Focus. pp 39.

88. Lübecker. The Feel-Bad Film. pp 31. 


\section{THE TRIBE}

Sound, perspective, and technological innovations are borderline invisible pieces of film unless the formula is shifted. Sound in The Tribe is the crucial and all encompassing marvel illuminating ableism but also forcing the spectator to listen carefully and watch, there is no understandable dialogue, through voice or subtitles, to give hints as to what the film is about, it takes full visual and auditory participation to understand the plot. Lübecker writing about similarly quiet films, though not to the same extent of the tribe, states "They gently push the spectator towards what Bataille described as definitive silence: the point where our social, political. Psychological and other rational discourses fall away. This silence is sometimes appealing and idyllic, but in these cases it is mostly worrying and disturbing." ${ }^{89}$ Ambient sound is the only soundtrack to this film, shuffling hands and exacerbated breaths. 'Worrying and disturbing' perfectly highlight the eery quality of silence in The Tribe.

In a scene of particularly heightened emotional charge one of the young deaf female students, who is trying to leave Ukraine and paying for it through prostitution, find out that she is pregnant. Through illegal channels she finds herself in a woman's home, for a abortion outside of traditional medical routes. The scene builds not from a swelling score or heightened emotional stakes, but the slow realization that the scene is not going to release us from the physical torture that is going to happen to this young woman. Before describing how the scene unfolds, Müsterberg poetically illustrated how a spectator would react to such subject matter

89. Ibid., pp 99. 
The horror which we see makes us really shrink... the pain which we observe brings contractions in our muscles; and all the resulting sensations from muscles, joints, tendons, from skin and viscera, from blood circulation and breathing, give the color of living experience to the emotional reflection in our mind. ${ }^{90}$

The student is sat on a cold flat surface raised above a bath tub, a clothing line with hoops for her feet on either side that is attached from one foot, threaded behind her back to her other foot for support as a rudimentary gynecological stirrup. The rope indents into her skin from the pressure. Thuds, shifts and muffled creaking of the house fill the auditory landscape until the inevitable metallic clanging of medical tools fill the room. So far in the film no sounds have left a characters lips other then breaths and grunts, the spectator becoming accustomed to the soundscape and lack of dialogue, not quiet but ambient and familiar, until the young student is penetrated by the recently sterilized, warm metal, tools in order to abort her pregnancy. Screams of a girl who has never heard herself scream, a primal need to find release from the pain. The camera is stagnant, showing the entire process every scrape and clatter of a new tool is punctuated by whimpers. The pain and turmoil she would have felt is unfathomable, her screams unique to the films landscape calls the scene to our attention.

Myroslav Slaboshpytskyi did not shy away from terror of those cast aside, these young students are kept hidden from the world as they are sanctioned off into their own school and taken advantage of by adults that are meant to care for them. The scene described above causes recoil and fascination, muscles clenching visualizing the pain she must be experiencing and feeling the back of your seat push firmly stop you from

90. Münsterberg. The Film. pp 53. 
escaping, as you try to get further away. However, this urge to get further away is contrasted by a curiosity to understand what is playing out in front of you. Both pulled in and repulsed confusing and frustrating the spectators sense of direction. The sound scape is captivating, echoing a response Sobchack had to watching the film Innocence (Hadzihalilovic 2004), “we find ourselves anxious about missing something-leaning forward and looking and listening... for those few images or sounds that suggest something known and familiar, that allow us to locate ourselves, even if for a moment, in a situation that largely eludes our grasp."91

\section{$\underline{\text { SON OF SAUL }}$}

Disorientation is the key factor behind László Nemes' Son of Saul, as the perspective of the camera keeps us from finding a solid footing. Traditional framing is replaced with a choreographed dance between the camera and the lead character Saul (Géza Röhrig). Nothing is steady other then the constant presence of Saul, in close up, throughout nearly the entire film. We become socially connected to Saul, and his emotional state becomes contagious. Seeing reactions to the horror going on around him, only showing glimpses of the horror through the out of focus peripheral imagery.

The intentionality of Sauls facial expression intensifies the ability for contagion, as the facial expressions of others is the key entry point for contagious affect. 92 "Imitation is 'suggested', then, both by the force of habit (the force of the past) and, more immediately, by the force of the sympathy that is the response to what is suggested by

91. Vivian Sobchack. 2005. "Waking Life: Vivian Sobchack on the Experience of Innocence." Film Comment 41 (6): 46-49. http://libproxy.chapman.edu/login?url=http://search.ebscohost.com/ login.aspx .direct=true \&AuthType $=\mathrm{ip}, \mathrm{uid} \& \mathrm{db}=$ mzh\&AN=2018131190\&site=eds-live. pp 45 .

92. Fuery. Wilfred Bion. pp 28. 
other bodies. "93 He creates a familial point of contact, seeing him care for and react to the horrors of the holocaust give the spectator a palpable recognition of the horror he is witnessing. We follow Saul through the concentration camps as he cleans the gas chambers as part of the Sonderkommando, Jewish prisoners who are rationed more food for their work on the chambers. "We spontaneously and contagiously focus our emotional attention on the other's situation..."94 Yearning to help this young man, he establishes a knowable paternal care of a young man who survived the chamber but was subsequently suffocated by the SS, his driving force is to give his 'son,' a proper kiddish funeral. A point of rebellion, finding a small sliver of humanity in his painful and hopeless reality. The holocaust is a group trauma that is unfathomable even for the people that survived through it, but it is in our cultural memory. Through lessons in school, films like Steven Spielberg's Schindler's list (1993), or documentaries like Claude Lanzermann's Shoah (1985) imagery of the holocaust can be recollected by many people. The fact that the violence of Son of Saul is not explicitly shown we fill in the gaps with out imagination. Chari Larsson writes "In order to know, we must imagine for ourselves" in "Making Monsters: László Nemes' Son of Saul"95 Without seeing the imagery of death and the piles of bodies being buried are out of focus, we must imagine them for ourselves. Implementing a way to know and understand the holocaust through our own personal understanding, creating images of composite memories from school and documentaries to truly work through the horror that is genocide.

93. Gibbs. "Panic! Affect Contagion.” pp 135.

94. Laine. Feeling Cinema. pp 46.

95. Chari Larsson. 2016. "Making Monsters in László Nemes' Son of Saul." Senses of Cinema, no. 81 (December): 1. 


\section{CONCLUSION}

It is hard to say how many of us have experienced the exact events depicted in these films, however, they still affect those who watch them. Their play with formal qualities exploit our human nature to imagine and empathize with characters on a screen to put us into viscerally uncomfortable positions. We who gravitate towards these films are moral masochists, trying work through an emotional state. To do this there needs to be an 'other mind,' but this other does not need to be a person it can be an object and in this case a film. 96 While the films chosen for this thesis are by no means the only affectively frustrating media objects, I have chosen them as an active spectator. These films forced me to take time and process what I had seen. Though, I would not say I am a moral masochist in the strictest definition. The melding of classical and contemporary psychoanalysis that has been explored in this thesis, allows for watching traumatic film to feel less alienating. By contextualizing moral masochism through contemporary psychoanalytic frames. This reorientation of moral masochism to separate it from its paradoxical roots and place it within a more tangible psychic understanding where the creation of frustration is a tool to advance emotional experience and to better cope with the frustrations of the world.

Art can be created to be positively affecting, serene and comfortable, but art that challenges and disrupts is beautiful in its ability to help us "examine who [we] are and why [we] think the way they do."97

96. Fuery. Wilfred Bion. pp 33.

97. Sally Mann 


\section{Bibliography}

Barzilai, Shuli. "Dickens's "Great Expectations": The Motive for Moral Masochism." American Imago 42, no. 1 (1985): 45-67. http://www.jstor.org.libproxy. chapman.edu/stable/26303580.

Bion, Wilfred R. 1984. Second Thoughts : Selected Papers on Psychoanalysis. London: Routledge.

—. 2013. "The Psycho-Analytic Study of Thinking." Psychoanalytic Quarterly. http:// icpla.edu/wp-content/uploads/2014/09/Bion-W.-A-theory-of-thinking-ThePsychoAnalytic-Study-of-Thinking.pdf.

Bollas, Christopher, and Sacha Bollas. 2013. Catch Them before They Fall: The Psychoanalysis of Breakdown. New York, NY: Routledge/Taylor \& Francis Group.

Brennan, Teresa. 2004. The Transmission of Affect. Ithaca : Cornell University Press, 2004.

Brinkema, Eugenie. 2014. The Forms of the Affects. Durham, NC: Duke UP.

Cartwright, Lisa. 2008. Moral Spectatorship : Technologies of Voice and Affect in Postwar Representations of the Child. Durham : Duke University Press.

Dyer, Richard. 2004. Heavenly Bodies : Film Stars and Society. London ; New York : Routledge, 2004.

Freud, Sigmund. 1924. “The Economic Problem of Masochism.” Essential Papers on Masochism. Edited by Margaret Ann Fitzpatrick Hanly. Essential Papers in Psychoanalysis. New York, NY: New York University Press. 1995. 
—. 2015. "Beyond the Pleasure Principle." Psychoanalysis and History, Sigmund Freud, Beyond the pleasure principle: New critical edition by Ulrike May and Michael Schröter, with commentary, 17 (2): 151-204.

Thomas, Paul. 1976. "Fassbinder: The Poetry of the Inarticulate." Film Quarterly 30 (2) Prince, Stephen. 2000. Screening Violence. Rutgers Depth of Field Series. New Brunswick, N.J. : Rutgers University Press, c2000.

Fuery, Kelli. 2018. Wilfred Bion, Thinking, and Emotional Experience with Moving Images: Being Imbedded. Abingdon, Oxon ; New York, NY : Routledge. Garcia, Carla Ambrósio. 2017. Bion in Film Theory and Analysis: The Retreat in Film. New York, NY: Routledge/Taylor \& Francis Group.

Geil, Abraham The Spectator without Qualities. 2013. Edinburgh University Press. https://www.academia.edu/10353920/The_Spectator_without_Qualities

Gibbs, Anna. 2011. "Panic! Affect Contagion, Mimesis and Suggestion in the Social Field." Cultural Studies Review, Vol 14, Iss 2 (2011), no. 2.

Gledhill, Christine. 1988. "The Melodramatic Field: An Investigation. (Undetermined)." Home Is Where the Heart Is, January, 5-39.

Hirsch, Joshua Francis. 2004. Afterimage: Film, Trauma, and the Holocaust. Emerging Media. Philadelphia : Temple University Press

Laine, Tarja. 2011. Feeling Cinema : Emotional Dynamics in Film Studies. New York: Continuum.

Larsson, Chari. 2016. “Making Monsters in László Nemes’ Son of Saul.” Senses of Cinema, no. 81 (December): 1. 
Lübecker, Nikolaj d'Origny. 2015. The Feel-Bad Film. Edinburgh Studies in Film and Intermediality. Edinburgh: Edinburgh University Press.

Marcantonio, Carla. 2015. Global Melodrama: Nation, Body, and History in Contemporary film. Palgrave Macmillan.

Massumi, Brian. 2013. "Translator's Forward: Pleasures of philosophy," A Thousand Plateaus: Capitalism and Schizophrenia. Deleuze, Gilles. Bloomsbury Revelations Series. Bloomsbury.

Mulvey, Laura. 1999. "Visual Pleasure and Narrative Cinema." In Feminist Film Theory: A Reader, edited by Sue Thornham, 58-69. New York, NY: New York UP. http:// search.ebscohost.com.libproxy.chapman.edu/login.aspx?direct=true\&Auth Type=ip,uid\&db=mzh\&AN=1999088302\&site=eds-live.

Munsterberg, Hugo. 1970. The Film : A Psychological Study: the Silent Photoplay in 1916. Dover Books in Psychology. Dover.

Plantinga, Carl, author. 2018. Screen Stories : Emotion and the Ethics of Engagement. New York: Oxford University Press.

Prince, Stephen. 2000. Screening Violence. Rutgers Depth of Field Series. New Brunswick, N.J. : Rutgers University Press, c2000.

Reilly, Phoebe. 2018. “Is ‘The Tale' HBO’s Most Controversial Movie Ever?” Rolling Stone. https://www.rollingstone.com/tv/tv-features/is-the-tale-hbos-mostcontroversial-movie-ever-630017/

Stadler, Jane. 2008. Pulling Focus : Intersubjective Experience, Narrative Film, and Ethics. Continuum. 
Sobchack, Vivian. 2005. "Waking Life: Vivian Sobchack on the Experience of Innocence." Film Comment 41 (6): 46-49. http://libproxy.chapman.edu/login? url=http://search.ebscohost.com/login.aspx? direct=true \&AuthType=ip,uid\&db=mzh\&AN=2018131190\&site=eds-live.

Sontag, Susan. 2003. Regarding the Pain of Others. New York : Farrar, Straus and Giroux. Walker, Janet. 2005. Trauma Cinema : Documenting Incest and the Holocaust. Berkeley: University of California Press.

Williams, Linda. 1991. “Film Bodies: Gender, Genre, and Excess.” Film Quarterly 44: 2-13. —. 1998. "Melodrama Revised.” Refiguring American Film Genres, January, 42-88.

Wilson, Emma. 2005. "Material Remains: Night and Fog." October 112: 89. Winnicott, Donald W. 2008. Playing and Reality. Routledge Classics. Routledge. Zimmermann, Jens. 2015. Hermeneutics: A Very Short Introduction. Very Short Introductions. Oxford: Oxford Univ Press. 


\section{Filmography}

Andrews, Benedict, et al. Una. Film4 Productions, 2016.

Fox, Jennifer, et al. The Tale. HBO Films, 2018.

Nemes, László, et al. Son of Saul. Sony Pictures Classics, 2015.

Slaboshpytskiy, Myroslav, et al. The Tribe. Harmata Film Production, 2014. 